\title{
Risk Factors and Rate of Recurrence after Mohs Surgery in Basal Cell and Squamous Cell Carcinomas: A Nationwide Prospective Cohort (REGESMOHS, Spanish Registry of Mohs Surgery)
}

\begin{abstract}
Alejandra TOMÁS-VELÁZQUEZ ${ }^{(1}{ }^{1}$, Onofre SANMARTIN-JIMÉNEZ ${ }^{0_{2}^{2}}$, Joan R. GARCÉS ${ }^{3,4}$, Manuel A. RODRÍGUEZ-PRIETO5 Verónica RUIZ-SALAS ${ }^{3,4}$, Esther DE EUSEBIO-MURILLO ${ }^{6}$, Román MIÑANO-MEDRANO ${ }^{7}$, Begoña ESCUTIA-MUÑOZ ${ }^{8}$, Ángeles FLÓREZ-MENÉNDEZ ${ }^{\circledR 9}$, Juan L. ARTOLA-IGARZA ${ }^{10}$, Alberto ALFARO-RUBIO@11, Pilar GIL ${ }^{1}$, Yolanda DELGADOJIMÉNEZ ${ }^{12,13}$, Julia M. SÁNCHEZ-SCHMIDT ${ }^{14}$, Irati ALLENDE-MARKIXANA ${ }^{15}$, María L. ALONSO-PACHECO ${ }^{16}$, Beatriz GARCÍA-BRACAMONTE ${ }^{17}$, Pablo DE LA CUEVA-DOBAO ${ }^{18}$, Raquel NAVARRO-TEJEDOR ${ }^{13}$, Cristina CIUDAD-BLANCO ${ }^{\circledR 19,20}$, Lucía CARNERO-GONZÁLEZ ${ }^{21}$, Hugo VÁZQUEZ-VEIGA ${ }^{22}$, Natividad CANO-MARTÍNEZ ${ }^{18,20}$, Eva VILARRASA-RULL ${ }^{3,4}$, Pedro SÁNCHEZ-SAMBUCETY ${ }^{\mathbb{S}_{5}}$, José L. LÓPEZ-ESTEBARANZ ${ }^{\mathbb{7} 7}$, Rafael BOTELLA-ESTRADA ${ }^{8}$, Beatriz GONZÁLEZ-SIXTO ${ }^{\mathbb{1} 9}$, Ántonio MARTORELL-CALATAYUD ${ }^{11}$, Victoriano MORALES-GORDILLO ${ }^{\mathbb{1}_{12}}$, Agustí TOLL-ABELLÓ ${ }^{14}$, Izascun OCERIN-GUERRA ${ }^{15}$, Matías MAYOR-ARENAL ${ }^{16}$, Ricardo SUÁREZ-FERNÁNDEZ ${ }^{\mathbb{1}_{19}}$, Laura SAINZ-GASPAR $^{\mathbb{1}_{21}}$, Miguel A. DESCALZO ${ }^{23}$, Ignacio GARCIADOVAL ${ }^{23,24}$ and Pedro REDONDO ${ }^{1}$; on behalf of REGESMOHS (Registro Español de Cirugía de Mohs)

${ }^{1}$ Clínica Universidad de Navarra, Pamplona, ${ }^{2}$ Instituto Valenciano de Oncología, Valencia, ${ }^{3}$ Hospital de la Santa Creu i Sant Pau, ${ }^{4}$ Centro Médico Teknon, Barcelona, ${ }^{5}$ Complejo Asistencial Universitario de León, León, ${ }^{6}$ Complejo Hospitalario Universitario de Guadalajara, Guadalajara, ${ }^{7}$ Hospital Universitario Fundación Alcorcón, Madrid, ${ }^{8} \mathrm{Hospital}$ Universitario La Fe, Valencia, ${ }^{9}$ Complexo Universitario Hospitalario Pontevedra, Pontevedra, ${ }^{10}$ Hospital de Galdakao, Galdakao, ${ }^{11}$ Hospital Manises, Valencia, ${ }^{12}$ Hospital Universitario Quirón Salud, ${ }^{13}$ Hospital Universitario de la Princesa, Madrid, ${ }^{14} \mathrm{Hospital}$ del Mar, Barcelona, ${ }^{15} \mathrm{Hospital}$ Universitario de Cruces, Barakaldo, ${ }^{16} \mathrm{Hospital} \mathrm{La} \mathrm{Paz,} \mathrm{Madrid,}{ }^{17} \mathrm{Hospital}$ Universitario Doce de Octubre, ${ }^{18} \mathrm{Hospital}$ Infanta Leonor, ${ }^{19} \mathrm{Hospital}$ General Universitario Gregorio Marañón, ${ }^{20} \mathrm{Hospital}$ La Zarzuela, Madrid,

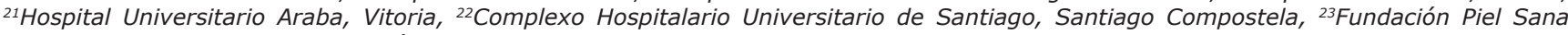
Academia Española de Dermatología, Madrid and ${ }^{24}$ Complexo Hospitalario Universitario de Vigo, Vigo, Spain
\end{abstract}

Randomized studies to assess the efficacy of Mohs micrographic surgery in basal cell and squamous cell carcinomas are limited by methodological and ethical issues and a lack of long follow-up periods. This study presents the "real-life" results of a nationwide 7-years cohort on basal cell carcinoma and squamous cell carcinoma treated with Mohs micrographic surgery. A prospective cohort was conducted in 22 Spanish centres (from July 2013 to February 2020) and a multivariate analysis, including characteristics of patients, tumours, surgeries and follow-up, was performed. A total of 4,402 patients followed up for 12,111 patientyears for basal cell carcinoma, and 371 patients with 915 patient-years of follow-up for squamous cell carcinoma were recruited. Risk factors for recurrence included age, non-primary tumours and more stages or unfinished surgeries for both tumours, and immunosuppression for squamous cell carcinoma. Incidence rates of recurrence were 1.3 per 100 person-years for basal cell carcinoma ( $95 \%$ confidence interval 1.11.5 ) and 4.5 for squamous cell carcinoma ( $95 \%$ confidence interval 3.3-6.1), being constant over time (0-5 years). In conclusion, follow-up strategies should be equally intense for at least the first 5 years, with special attention paid to squamous cell carcinoma (especially in immunosuppressed patients), elderly patients, non-primary tumours, and those procedures requiring more stages, or unfinished surgeries.

Key words: basal cell carcinoma; squamous cell carcinoma; Mohs surgery; recurrence; risk factors.

Accepted Oct 25, 2021; Epub ahead of print Oct 25, 2021

Acta Derm Venereol 2021; 101: adv00602.

Corr: Alejandra Tomás Velázquez, Research Unit, Fundación Piel Sana, Academia Española de Dermatología y Venereología, Calle Ferraz 100, 10 izda, ES-28008 Madrid, Spain. E-mail: atomasv@unav.es

\section{SIGNIFICANCE}

Mohs micrographic surgery is the treatment of choice for high-risk basal cell carcinoma and squamous cell carcinoma. Its efficacy and recurrence risk factors should be studied in large prospective cohorts. This paper presents the results of the first European nationwide 7-years cohort on basal cell carcinomas and squamous cell carcinomas treated with Mohs micrographic surgery. The results show that recurrences are low, but do occur. In conclusion, follow-up should be equally intense for at least the first 5 years, and more intense in patients with squamous cell carcinoma (especially immunosuppressed patients), elderly patients, recurrent and persistent tumours, and in those patients who have had procedures requiring more stages or unfinished surgeries.

$\mathrm{B}$ asal cell carcinoma (BCC) and squamous cell carcinoma (SCC) are the most common skin malignancies $(1,2)$. The incidence of both tumours is increasing (3-5). Mohs micrographic surgery (MMS) combines a high cure rate with complete margin examination and healthy tissue conservation (6). MMS is the first-line therapy in high-risk BCC and SCC (such as those which are recurrent or incompletely excised, mid-facial located, or which show aggressive histological features or perineural invasion) (7-10).

Randomized clinical trials have demonstrated the greater efficacy of MMS compared with standard surgery for recurrent BCC (11-13) and tissue-sparing with MMS (14).

Some factors have been reported to be associated with recurrence, such as treating recurrent tumours, multiple stages of MMS excision or Breslow depth $(8,15,16)$. 
However, risk factors have not been consistent between studies.

Previous observational studies describing the effectiveness of MMS to treat BCC and SCC in real-life are subject to important caveats, in that they are mainly single-centre studies or retrospective in nature, with uncertain or large numbers of losses to follow-up, and different follow-up periods (17). The need for a prospective study with comprehensive data capture and standardized follow-up for SCC has been highlighted recently (18).

We report here the results of the first European nationwide 7-year prospective cohort on MMS, REGESMOHS (Spanish registry of Mohs Surgery). The aim of this study is to describe the risk factors for recurrence after MMS for BCC and SCC, the effectiveness in terms of rates for recurrence, and the change in recurrence rates over time.

\section{MATERIALS AND METHODS}

A detailed description of the Registro Español de Cirugía de Mohs (REGESMOHS) prospective cohort has been published previously $(19,20)$. All consecutive patients considered for MMS from 22 participating Spanish hospitals were included in the registry. The sample represented a large percentage of all dermatology clinics performing MMS (more than 1 intervention per week) in Spain (21).

The registry was established in July 2013 to collect information on the characteristics of patients, tumours, and surgeries performed. Histological markers of aggressive tumours and level of invasion were registered. The location of the tumour was classified according to risk areas (H-M-L; 7). Patient follow-up was performed, according to usual practice. Data had to be updated in the registry within 1 month after surgery and at least once a year. If patients missed appointments, they were contacted by telephone. Recurrences were diagnosed clinically (tumour reappearance within the scar) and confirmed histologically in most cases. All researchers received training on the study methods before joining the registry. The information was collected online, and its quality was systematically checked through monthly online monitoring. On-site monitoring was performed periodically.

The duration of the study was based on pre-planned sample size calculation. As the recruitment was slower than expected, the duration of the study was increased by 1 year.

\section{Statistical analysis}

This report included only those patients who underwent surgery for BCC or SCC. A descriptive analysis was performed using onset of a first recurrence as the main outcome. Continuous variables were expressed as means with standard deviations for symmetrical distributions, or medians and interquartile ranges for asymmetrical variables. Categorical variables were expressed as total numbers with percentages. Descriptive data were compared individually between analysis groups and recurrence using the Mann-Whitney $U$ test (or the Student's $t$-test, when necessary) and Pearson's $\chi^{2}$ test (or Fisher's exact test when necessary) depending on the distribution of the variables.

Incidence rates of recurrences with $95 \%$ confidence intervals ( $95 \% \mathrm{CI}$ ) were calculated by dividing the number of recurrences by the patient-years of follow-up. Risk factors associated with recurrences were estimated using a mixed-effect Poisson regression model considering the hospital as a random effect and the year of surgery as a fixed effect. Forward selection models were constructed using those variables with $p$-values $<0.2$ in the crude models. Final models were chosen using the likelihood-ratio test.

Cumulative incidence curves were used to represent survival time from surgery to recurrence of tumour, under a competing risk survival scenario. Death was considered the main competing factor for recurrence. Data were analysed using Stata 16.1 (StataCorp, College Station, TX, USA) and $p$-values less than 0.05 were considered statistically significant. REGESMOHS was approved by the Clinical Research Ethics Committee in Navarra (EO11/2013).

\section{RESULTS}

\section{Characteristics of patients, tumours and surgeries}

From July 2013 to February 2020, 5,226 patients were included in the REGESMOHS registry. A total of 453 patients had diagnoses other than $\mathrm{BCC}$ and $\mathrm{SCC}$ and were excluded from the study, leaving 4,402 patients with BCC and 371 with SCC. Their demographic characteristics are described in Table I.

Most procedures were performed under local anaesthesia, but sedation or general anaesthesia were used in some patients (10\%) (Table II).

The fresh-tissue technique was performed in 93\% of cases and slow Mohs in 7\% of cases. Free margins were achieved in $57 \%$ of the surgeries with 1 stage, $11 \%$ required 3 or more stages and $2 \%$ did not achieve complete excision (unfinished surgeries). Dermatologists participated in the interpretation of histology (71\%), commonly with a pathologist (87\%), and reconstructed the defect (97\%) in most cases.

\section{Risk factors for recurrence after Mohs surgery}

For BCC, univariate analysis showed an association between recurrence and being elderly, tumours of longer duration, recurrent or persistent tumours, previous therapeutic attempts (both surgical and non-surgical), asymmetry, and markers of complex surgery (longer surgery, higher number of stages, depth of the defect, hospitalization, and surgical morbidity) (Tables I-III). Since many of the variables measure similar domains, multivariate analysis reduced the number of variables associated with recurrence. After adjustment, for every 10 years of increasing age, the risk of recurrence increased by $24 \%$. Persistent and recurrent tumours, as well as those requiring a higher number of surgical stages had a nearly 2 -fold risk of recurrence. Unfinished surgery was the variable showing the strongest association with recurrence (IRR [incidence rate ratio] 4.49 (95\% CI 2.33-8.66)).

Regarding SCC, univariate analysis showed an increased risk of recurrence for immunosuppressed patients, recurrent or persistent and asymmetrical tumours, and patients who required longer interventions, with deeper extent of the tumour and more surgical stages. Multivariate analysis showed that the main risk factors for recurrence were immunosuppression (IRR 2.87 
Table I. Description of the study population and univariate risk factors for recurrence: characteristics of patients and tumours

\begin{tabular}{|c|c|c|c|c|c|c|c|}
\hline \multirow[b]{2}{*}{ Characteristics } & \multirow{2}{*}{$\begin{array}{l}\text { Study } \\
\text { population* } \\
n=4,773\end{array}$} & \multicolumn{2}{|c|}{ Recurrence in BCC } & \multirow[b]{2}{*}{$p$-value } & \multicolumn{2}{|c|}{ Recurrence in SCC } & \multirow[b]{2}{*}{$p$-value } \\
\hline & & $\begin{array}{l}\text { No } \\
n=4,248(\%)\end{array}$ & $\begin{array}{l}\text { Yes } \\
n=154(\%)\end{array}$ & & $\begin{array}{l}\text { No } \\
n=330(\%)\end{array}$ & $\begin{array}{l}\text { Yes } \\
n=41(\%)\end{array}$ & \\
\hline \multicolumn{8}{|l|}{ Patients } \\
\hline Sex (male), $n(\%)$ & $2,458(52)$ & $2,121(50)$ & $79(51)$ & 0.7385 & $225(68)$ & $33(80)$ & 0.1064 \\
\hline Age, years, median (IQR) & $70.8(59.3-79.5)$ & $70.6(59.4-79.5)$ & $74.5(66.5-80.7)$ & 0.0029 & $76.9(65.8-83.1)$ & $75(69.5-81.9)$ & 0.8286 \\
\hline Immunosuppression, $n(\%)$ & $149(3)$ & $109(3)$ & $8(5)$ & 0.0658 & $22(7)$ & $10(24)$ & 0.0010 \\
\hline Diabetes mellitus, $n(\%)$ & $562(12)$ & $478(11)$ & $20(14)$ & 0.4034 & $57(18)$ & $7(17)$ & 0.9139 \\
\hline Multiple tumour syndromes, $n(\%)$ & $113(2)$ & $100(2)$ & $3(2)$ & 1.0000 & $10(3)$ & $0(0)$ & 0.6100 \\
\hline \multicolumn{8}{|l|}{ Tumours } \\
\hline Time since appearance, months, median (IQR) & $14.3(6.8-34.2)$ & $14.3(6.7-33.4)$ & $19.3(8.4-37)$ & 0.0283 & $9.2(5-19.5)$ & $9.3(4.1-28.1)$ & 0.8384 \\
\hline Size, $\mathrm{mm}, n(\%)$ & & & & 0.3299 & & & 0.1679 \\
\hline$<10$ & $1,929(41)$ & $1,765(42)$ & $58(38)$ & NA & $98(31)$ & $8(20)$ & NA \\
\hline$\geq 10$ & $2,746(59)$ & $2,398(58)$ & $93(62)$ & NA & $223(69)$ & $32(80)$ & NA \\
\hline Type, $n(\%)$ & & & & 0.0000 & & & 0.0295 \\
\hline Primary & $3,008(63)$ & $2,720(64)$ & $70(45)$ & NA & $201(61)$ & $17(41)$ & NA \\
\hline Recurrent & $979(21)$ & $857(20)$ & $47(31)$ & NA & $61(18)$ & $14(34)$ & NA \\
\hline Persistent & $786(16)$ & $671(16)$ & $37(24)$ & NA & $68(21)$ & $10(24)$ & NA \\
\hline Zone, $n(\%)$ & & & & 0.0482 & & & 0.4111 \\
\hline H-Area & $3,813(80)$ & $3,441(82)$ & $114(74)$ & NA & $232(71)$ & $26(63)$ & NA \\
\hline M-Area & $901(19)$ & $756(18)$ & $39(25)$ & NA & $91(28)$ & $15(37)$ & NA \\
\hline L-Area & $26(1)$ & $20(0)$ & $1(1)$ & NA & $5(2)$ & $0(0)$ & NA \\
\hline Histologically aggressive, $n(\%)$ & $3,402(71)$ & $3,028(71)$ & $104(68)$ & 0.3132 & $239(72)$ & $31(76)$ & 0.6656 \\
\hline Previous surgical treatments, $n(\%)$ & $856(18)$ & $719(17)$ & $48(31)$ & 0.0000 & $77(23)$ & $12(29)$ & 0.4074 \\
\hline Previous non-surgical treatments, $n(\%)$ & $232(5)$ & $190(4)$ & $14(9)$ & 0.0058 & $22(7)$ & $6(15)$ & 0.1065 \\
\hline
\end{tabular}

*Some proportions cannot be calculated from the table due to few missing data on the variable.

BCC: basal cell carcinoma; SCC: squamous cell carcinoma; NA: non-applicable; IQR: interquartile range. Bold indicates statistically significant results.

Table II. Univariate risk factors for recurrence: characteristics of surgery

\begin{tabular}{|c|c|c|c|c|c|c|}
\hline \multirow[b]{2}{*}{ Surgery characteristics } & \multicolumn{3}{|c|}{ Recurrence in BCC } & \multicolumn{2}{|c|}{ Recurrence in SCC } & \multirow[b]{2}{*}{$p$-value } \\
\hline & $\begin{array}{l}\text { No } \\
n=4,248(\%)\end{array}$ & $\begin{array}{l}\text { Yes } \\
n=154(\%)\end{array}$ & $p$-value & $\begin{array}{l}\text { No } \\
n=330(\%)\end{array}$ & $\begin{array}{l}\text { Yes } \\
n=41(\%)\end{array}$ & \\
\hline Time from pre-surgical consultation to surgery, months, median (IQR) & $1.5(0.9-2.6)$ & $1.6(1-2.6)$ & 0.5187 & $1.1(0.5-2.2)$ & $0.7(0.4-1.7)$ & 0.1934 \\
\hline Time in operating room, min*, median (IQR) & $75(60-100)$ & $90(60-120)$ & 0.0212 & $80(55-110)$ & $90(60-122)$ & 0.0324 \\
\hline Defect difference (major axis - minor axis in $\mathrm{mm}$ ), median (IQR) & $4(1-8)$ & $5(2-10)$ & 0.0179 & $5(0-10)$ & $10(5-20)$ & 0.0030 \\
\hline Hospitalization, $n(\%)$ & $689(17)$ & $39(27)$ & 0.0017 & $94(30)$ & $15(44)$ & 0.1035 \\
\hline Mohs surgery types, $n(\%)$ & & & 0.5458 & & & 0.079 \\
\hline Fresh-tissue technique & $4,025(95)$ & $143(93)$ & NA & $237(72)$ & $24(59)$ & NA \\
\hline Slow Mohs & $220(5)$ & $10(7)$ & NA & $93(28)$ & $17(41)$ & NA \\
\hline Number of stages, $n(\%)$ & & & 0.0002 & & & 0.0002 \\
\hline 1 & $2,407(57)$ & $62(41)$ & NA & $204(62)$ & $15(37)$ & NA \\
\hline 2 & $1,360(32)$ & $63(41)$ & NA & $104(32)$ & $17(41)$ & NA \\
\hline 3 or more & $458(11)$ & $27(18)$ & NA & $20(6)$ & $9(22)$ & NA \\
\hline Number of blocks, $n(\%)$ & & & 0.3206 & & & 0.2745 \\
\hline 1 & $391(10)$ & $8(6)$ & NA & $35(11)$ & $2(5)$ & NA \\
\hline 2 & $1,115(28)$ & $34(27)$ & NA & $62(20)$ & $5(14)$ & NA \\
\hline 3 or more & $2,464(62)$ & $86(67)$ & NA & $211(69)$ & $30(81)$ & NA \\
\hline Unfinished surgery & $56(1)$ & $11(7)$ & 0.0000 & $11(3)$ & $7(17)$ & 0.0001 \\
\hline Extent level, $n(\%)$ & & & 0.0128 & & & 0.0048 \\
\hline Epidermis & $26(1)$ & $4(3)$ & NA & $10(3)$ & $2(5)$ & NA \\
\hline Dermis & $2,049(50)$ & $63(43)$ & NA & $106(33)$ & $9(22)$ & NA \\
\hline Hypodermis & $1,678(41)$ & $61(41)$ & NA & $138(44)$ & $11(27)$ & NA \\
\hline Fascia & $108(3)$ & $6(4)$ & NA & $15(5)$ & $6(15)$ & NA \\
\hline Muscle & $242(6)$ & $11(7)$ & NA & $39(12)$ & $11(27)$ & NA \\
\hline Bone & $27(1)$ & $3(2)$ & NA & $9(3)$ & $2(5)$ & NA \\
\hline Specialist who repaired, $\mathrm{n}(\%)$ & & & 0.8831 & & & 0.7324 \\
\hline Dermatologist & $4,149(98)$ & $148(98)$ & & $316(96)$ & $41(100)$ & \\
\hline Plastic surgeon & $36(1)$ & $1(1)$ & & $3(1)$ & $0(0)$ & \\
\hline Other & $45(1)$ & $2(1)$ & & $11(3)$ & $0(0)$ & \\
\hline Reconstruction technique, $n(\%)$ & & & 0.0294 & & & 0.1140 \\
\hline Healing by secondary intention & $484(11)$ & $17(11)$ & NA & $68(21)$ & $10(24)$ & NA \\
\hline Direct closure & $1,128(27)$ & $42(27)$ & NA & $87(26)$ & $10(24)$ & NA \\
\hline Flap & $1,993(47)$ & $58(38)$ & NA & $103(31)$ & $10(24)$ & NA \\
\hline Graft & $498(12)$ & $31(20)$ & NA & $62(19)$ & $6(15)$ & NA \\
\hline Complete closure & $142(3)$ & $5(3)$ & NA & $10(3)$ & $5(12)$ & NA \\
\hline Dermatologist participates in the interpretation, $n(\%)$ & $3,129(74)$ & $91(59)$ & 0.0001 & $202(61)$ & $21(51)$ & 0.2091 \\
\hline Pathologist participates in the interpretation, $n(\%)$ & $3,221(76)$ & $140(92)$ & 0.0000 & $296(90)$ & $38(93)$ & 0.5804 \\
\hline Intra or post-surgical morbidity, $n(\%)$ & $277(7)$ & $16(11)$ & 0.0478 & $26(8)$ & $6(15)$ & 0.1535 \\
\hline
\end{tabular}

*Time waiting outside operating room was excluded.

BCC: basal cell carcinoma; SCC: squamous cell carcinoma; NA: non-applicable; IQR: interquartile range. Bold $p$-values indicate statistically significant results. 
Table III. Multivariate analysis: risk factors for recurrence

\begin{tabular}{|c|c|c|}
\hline Characteristics & $\begin{array}{l}\text { Incidence rate ratio } \\
95 \% \mathrm{CI}\end{array}$ & $p$-value \\
\hline \multicolumn{3}{|l|}{$B C C$} \\
\hline Age, in years & $1.02(1-1.03)$ & 0.0099 \\
\hline \multicolumn{3}{|l|}{ Type } \\
\hline Primary & Reference & \\
\hline Recurrent & $1.78(1.20-2.63)$ & 0.0040 \\
\hline Persistent & $1.89(1.25-2.86)$ & 0.0025 \\
\hline \multicolumn{3}{|l|}{ Number of stages } \\
\hline 1 & Reference & \\
\hline 2 & $1.62(1.11-2.35)$ & 0.0116 \\
\hline 3 or more & $1.93(1.17-3.17)$ & 0.0098 \\
\hline Unfinished surgery & $4.49(2.33-8.66)$ & 0.0000 \\
\hline Pathologist participates in the interpretation & $2.42(1.01-5.78)$ & 0.0469 \\
\hline \multicolumn{3}{|c|}{ Technique } \\
\hline Healing by secondary intention & Reference & \\
\hline Direct closure & $1.65(0.89-3.05)$ & 0.1096 \\
\hline Flap & $0.97(0.53-1.78)$ & 0.9319 \\
\hline Graft & $1.76(0.93-3.32)$ & 0.0822 \\
\hline Complete closure & $0.72(0.25-2.03)$ & 0.5303 \\
\hline \multicolumn{3}{|l|}{ SCC } \\
\hline Immunosuppression & $2.87(1.28-6.45)$ & 0.0106 \\
\hline \multicolumn{3}{|l|}{ Number of stages } \\
\hline 1 & Reference & \\
\hline 2 & $3.83(1.69-8.71)$ & 0.0014 \\
\hline 3 or more & $4.15(1.41-12.26)$ & 0.0100 \\
\hline Unfinished surgery & $6.71(2.74-16.42)$ & 0.0000 \\
\hline Defect diff. $(\mathrm{mm})$ & $1.03(1.01-1.05)$ & 0.0060 \\
\hline
\end{tabular}

(95\% CI 1.28-6.45)), a larger number of stages, and unfinished surgery, which increased the risk or recurrence by nearly 7 times (Table III).

In the overall population, the adjusted IRR of recurrence was 2.53 (95\% CI 1.74-3.69) times higher for SCC than for BCC.

Incidence of recurrence after Mohs surgery, diagnosis, and therapeutic approach

Patients were followed-up for a mean \pm standard deviation of $2.7 \pm 1.6$ years, reaching 12,111 patient-years for the
Table IV. Incidence of recurrence, diagnosis, and approach

\begin{tabular}{|c|c|c|}
\hline & $\begin{array}{l}\text { BCC } \\
4,402(84.2)\end{array}$ & $\begin{array}{l}\text { SCC } \\
371(7.1)\end{array}$ \\
\hline Patient-years follow-up, $n(\%)$ & 12,111 & 915 \\
\hline Average follow-up time, years, mean (SD) & $2.8(1.6)$ & $2.5(1.6)$ \\
\hline $\begin{array}{l}\text { Patients lost to follow-up prior to recurrence, } \\
n(\%)\end{array}$ & $688(15.6)$ & $45(12.1)$ \\
\hline Deaths, $n(\%)$ & $155(3.5)$ & $47(12.7)$ \\
\hline Recurrences, $n(\%)$ & $154(3.5)$ & $41(11.1)$ \\
\hline All tumours ${ }^{a}$ & $1.3(1.1-1.5)$ & $4.5(3.3-6.1)$ \\
\hline Primary tumours ${ }^{a}$ & $0.9(0.7-1.2)$ & $3.2(2.0-5.1)$ \\
\hline Recurrent tumours ${ }^{a}$ & $1.8(1.4-2.4)$ & $7.7(4.6-13.1)$ \\
\hline Persistent tumours ${ }^{a}$ & $2.0(1.4-2.7)$ & $5.1(2.7-9.4)$ \\
\hline \multicolumn{3}{|l|}{ Number of recurrences } \\
\hline 1 & $136(88)$ & $33(80)$ \\
\hline 2 & $13(8)$ & $7(17)$ \\
\hline 3 or more & $5(2)$ & $1(2)$ \\
\hline \multicolumn{3}{|l|}{ Diagnosis } \\
\hline Clinical & $21(25)$ & $8(36)$ \\
\hline Histological & $63(75)$ & $14(64)$ \\
\hline \multicolumn{3}{|l|}{ Treatment } \\
\hline Re-intervention & $116(75)$ & $24(59)$ \\
\hline Radiotherapy & $10(6)$ & $10(24)$ \\
\hline Chemotherapy & $1(0.7)$ & NA \\
\hline Hedgehog inhibitors & $6(4)$ & NA \\
\hline Tyrosine kinase inhibitors & $2(1.3)$ & NA \\
\hline Other options & $17(11)$ & $5(12)$ \\
\hline Palliative care & $2(1.3)$ & $2(5)$ \\
\hline
\end{tabular}

${ }^{a}$ Incidence per 100 person-years $95 \%$ confidence interval.

BCC: basal cell carcinoma; SCC: squamous cell carcinoma; NA: non-applicable.

BCC group and 915 patient-years for the SCC group. During follow-up, $3.5 \%$ of patients with BCC and $12.7 \%$ of SCC patients died (4.2\% mortality) and 788 patients $(15 \%)$ were lost to follow-up prior to any recurrence. Recurrence was histologically confirmed in most cases (75\% of BCCs and $64 \%$ of SCCs).

For patients with BCC, 3.5\% experienced recurrences $(n=154)$, with an incidence of 1.3 cases per 100 person-years (95\% CI 1.1-1.5). SCC patients presented a higher recurrence rate $(n=41 ; 11 \% ; 4.5$ cases per 100 person-years; 95\% CI 3.3-6.1) (Table IV). The cumulative incidences of recurrence for both BCC and SCC are shown in Fig. 1, which shows that the rate of recurrence

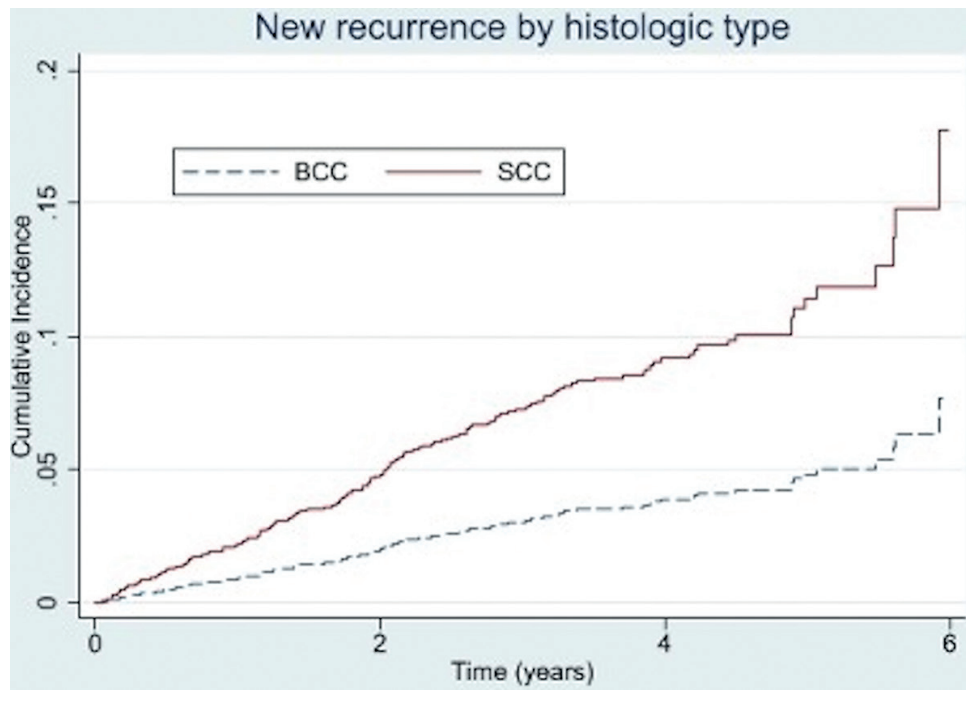

Fig. 1. Cumulative incidence curves of recurrence in basal cell carcinoma (BCC) and squamous cell carcinoma (SCC) patients treated with Mohs micrographic surgery (MMS). Each line represents the probability of cumulative recurrence over time considering death as a competing risk factor. The linear pattern implies a constant rate. 
increases consistently over time for BCC and SCC, but is approximately 2-fold higher in SCC groups in the period from 0 to 5 years.

Among recurrent cases, $10 \%$ of BCCs and 19\% of SCCs experienced 2 or more recurrences. The most frequent treatment for recurrence was a repeat operation (75\% in BCC and 59\% in SCC), with radiotherapy also being a common option for SCC (24\%) (Table IV).

\section{DISCUSSION}

We report here the results from REGESMOHS, which is, to our knowledge, the first European nationwide prospective cohort on MMS. Several risk factors for recurrence are described, including patient characteristics and tumour and surgical variables, which can help identify patients requiring closer monitoring. Overall, the study reports low recurrence rates for BCC and SCC treated with MMS, supporting the efficacy of this treatment modality.

This study has several strengths. It is prospective, multicentre, and representative of MMS in Spain (21). It reproduces previous research in a different setting and has been performed under strict quality standards, including pre-training of participants, and continuous monthly on-line monitoring. Nevertheless, some limitations of this study should be noted. Firstly, losses to follow-up represent an important limitation in long-term cohorts. However, losses of $15 \%$, as in the current study, are commonly considered acceptable in long-term studies. Secondly, as it was a nationwide study, a certain degree of heterogeneity is possible in the patients and surgical methods described. To mitigate this effect, a multilevel analysis approach was taken, considering the centre as a random effect. This weakness is balanced with increased external validity. Two considerations should be taken into account when comparing results with other countries. Most hospitals participating in the study belong to the Spanish public health system, which presents, in certain locations, waiting lists of months. Another difference is that, in Spain, pathologists frequently participate in MMS interpretation, which differs from other countries, such as the USA, where dermatologists perform the histological analysis. Both facts could have influenced results, and thus they were described in the results.

\section{Risk factors for recurrence}

The main risk factors for recurrence of $\mathrm{BCC}$, in order of decreasing importance, were unfinished surgery, recurrent or persistent tumours, and the need for more than 2 stages (as a measure of tumour infiltration). Other tumour characteristics classically associated with poor prognosis, such as aggressive histology or size, become less important when performing MMS and were not relevant in our models. These results agree with previous studies, such as the Australian nationwide series $(8,15$,
22). The fact that participation of a pathologist in the interpretation was also associated in the current study with an increased risk of recurrence was probably due to this factor acting as a proxy for more difficult diagnosis or increased tumour depth, without implying causality.

The main risk factors for recurrence of SCC were unfinished surgery, the number of stages needed, immunosuppression and asymmetrical growth. SCC diagnosis is also a risk factor for recurrence, as these lesions are twice as likely to recur than are BCC lesions. Previous studies have included the number of stages as a predictor of recurrence (23). Marrazzo et al (24). reported that, in high-risk cutaneous SCCs, invasion beyond the subcutaneous fat and poor histological differentiation were positively associated with local recurrence, nodal metastasis and disease-specific death. Tschetter et al. (16) have also recently found Breslow depth to be statistically associated with those 3 outcomes, while they found no association between recurrence and perineural invasion. The presence of immunosuppression is a known risk factor for death in SCC (25).

\section{Rates of recurrence}

Rates of recurrence for both tumours were 1.3 (95\% CI $1.1-1.5)$ recurrences per 100 person-years for $\mathrm{BCC}$ and 4.5 (95\% CI 3.3-6.1) for SCC. The rates of recurrence were constant over the follow-up period. In terms of risk, there was a $3.5 \%$ risk of recurrence for $\mathrm{BCC}$ after a mean follow-up of 2.8 years, and $11.1 \%$ for SCC after a mean follow-up of 2.5 years.

Although the risk of recurrence can be affected by the population studied, there are no large differences between the current study and those previously published in the USA or Australia (20).

Few prospective studies have previously estimated the recurrence risks for BCC and SCC after MMS.

The most quoted study, by Leibovitch et al. (15), reported an overall recurrence risk of $2.6 \%$ in 3,370 Australian patients with BCC followed for 5 years. This is equivalent to a rate of 0.5 recurrences per 100 personyears. However, the 3,370 patients included in their paper represent only $30 \%$ of the recruited population. The percentage lost to follow-up in this study was not reported, and it is likely to represent an important threat to its validity. Other authors have reported recurrence risks of between $0.7 \%$ and $6.7 \%$ for BCC at different time-periods $(22,26-31)$, but these data come from retrospective studies (26-31), from single centres (26-30), report results in limited areas of the body $(30,31)$, have few events, leading to imprecise results (26), include no description of losses to follow-up and other uncertain methods (27-29), describe risks instead of rates (26-31), or have highly variable lengths of follow-up (30).

The same Australian group reported an overall 5-year recurrence risk of $3.9 \%$ in 381 SCC patients who com- 
pleted a 5-year follow-up $(8,32)$. This is equivalent to a rate of recurrence of 0.7 per 100 person-years. Again, these data were calculated on the $30 \%$ of the recruited patients who completed 5 years of follow-up. The results in the remaining $70 \%$ were not reported, nor were the losses to follow-up; hence these estimates have a very low validity. Recently, Tschetter et al. (16) presented a prospective, multicentre analysis of 637 patients from the USA who were undergoing MMS for invasive SCC, with a risk of recurrence of $2.3 \%$ after a mean followup of 4 years, with $8 \%$ of losses to follow-up and $22 \%$ of deaths in the study period. Other results of recurrence describe values between $1.2 \%$ and $8 \%$ for SCC $(23,27,31,33,34)$. Unfortunately, many of these are retrospective studies $(23,27,31,33,34)$, have variable follow-up periods, and report risks at different times that are difficult to compare $(23,31,34)$. Furthermore, they do not clearly describe their methods and losses to follow-up $(23,27,31,33,34)$, or represent outcomes of 1 or a small group of dermatologists $(23,33,34)$ or a certain area of the body $(31,33)$, leading to poor internal or external validity.

It is interesting to note that the rates of recurrence, although low, remained constant over the study period, implying the need for the same intensity of follow-up at least during the first 5 years after surgery. Previous reports have also highlighted the need to follow patients for longer than 5 years (22).

We believe that the improved methods of the multicentre prospective cohort in the current study explain the higher, and more realistic, rates of recurrence. The external validity of the current study is also increased, as the study was carried out nationwide, in a country with a long experience of MMS and a case-mix similar to that reported in other countries $(20,21)$.

We describe here the "real-life" results of MMS for BCC and SCC, which are more likely to be valid than previous findings. The recurrence rate was low for $\mathrm{BCC}$ (1.3 recurrences per 100 person-years) and higher for SCC (4.5 per 100 person-years). Risk factors for recurrence include: age, non-primary tumours, procedures requiring more stages of surgery, or unfinished surgery for both tumours, and immunosuppression for SCC. The rate of recurrence was constant over the study period. These results should be taken into consideration when informing patients of the prognosis, planning follow-up, and might be useful when making decisions about additional systemic therapy. They also highlight the difficulty of performing randomized clinical trials in these patients due to the low recurrence rates.

\section{ACKNOWLEDGEMENTS}

The authors thank all participants and patients included in this cohort for their collaboration and involvement in this study. This work was conducted within the REGESMOHS Study Group. In addition to the authors, the following members participated in the acquisition of data: Arantxa Rodríguez Hernández (Instituto Valenciano de Oncología, Valencia, Spain); Eduardo Varas Meis (Complejo Asistencial Universitario de León, León, Spain); Azucena Sanz (Hospital Universitario Fundación Alcorcón, Madrid, Spain); Carlos Feal Cortizas (Complexo Universitario Hospitalario Pontevedra, Pontevedra, Spain); Pilar Gómez Palencia (Hospital Manises, Valencia, Spain); Gloria Soriano, (Clínica Universidad de Navarra, Pamplona, Spain); Matías Mayoral (Hospital La Paz, Madrid, Spain); Carmen García Donoso, $\mathrm{M}^{\mathrm{a}} \mathrm{del}$ Mar Onteniente Gomis (Hospital Universitario Doce de Octubre, Madrid, Spain); Catiana Silvente, Diana Velázquez (Hospital Infanta Leonor, Madrid, Spain); Cristina Santamaria Dominguez (Hospital Universitario de la Princesa, Madrid, Spain), Desiree Molina (Hospital General Universitario Gregorio Marañón, Madrid, Spain); Pablo Lázaro Ochaita, Lucía Barchino (Hospital La Zarzuela, Madrid, Spain).

REGESMOHS (Registro Español de Cirugía de Mohs) was promoted by Fundacion Piel Sana AEDV, with financial support from Roche Pharma. This publication has received unrestricted financial support from Sun Pharma. Roche Pharma and Sun Pharma have not participated in the design, analysis, or interpretation of the data.

The authors have no conflicts of interest to declare.

\section{REFERENCES}

1. Lomas A, Leonardi-Bee J, Bath-Hextall F. A systematic review of worldwide incidence of nonmelanoma skin cancer. $\mathrm{Br}$ J Dermatol 2012; 166: 1069-1080.

2. Tejera-Vaquerizo A, Descalzo-Gallego MA, Otero-Rivas MM, Posada-Garcia C, Rodriguez-Pazos L, Pastushenko I, et al. Skin cancer incidence and mortality in spain: a systematic review and meta-analysis. Actas Dermosifiliogr 2016; 107: 318-328.

3. Dessinioti C, Antoniou C, Katsambas A, Stratigos AJ. Basal cell carcinoma: what's new under the sun. Photochem Photobiol 2010; 86: 481-491.

4. Peris K, Fargnoli MC, Garbe C, Kaufmann R, Bastholt L, Seguin NB, et al. Diagnosis and treatment of basal cell carcinoma: European consensus-based interdisciplinary guidelines. Eur J Cancer 2019; 118: 10-34.

5. Que SKT, Zwald FO, Schmults CD. Cutaneous squamous cell carcinoma: incidence, risk factors, diagnosis, and staging. J Am Acad Dermatol 2018; 78: 237-247.

6. Shriner DL, McCoy DK, Goldberg DJ, Wagner RF, Jr. Mohs micrographic surgery. J Am Acad Dermatol 1998; 39: 79-97.

7. Ad Hoc Task F, Connolly SM, Baker DR, Coldiron BM, Fazio MJ, Storrs PA, et al. AAD/ACMS/ASDSA/ASMS 2012 appropriate use criteria for Mohs micrographic surgery: a report of the American Academy of Dermatology, American College of Mohs Surgery, American Society for Dermatologic Surgery Association, and the American Society for Mohs Surgery. J Am Acad Dermatol 2012; 67: 531-550.

8. Leibovitch I, Huilgol SC, Selva D, Hill D, Richards S, Paver R. Cutaneous squamous cell carcinoma treated with Mohs micrographic surgery in Australia I. Experience over 10 years. J Am Acad Dermatol 2005; 53: 253-260.

9. Leibovitch I, Huilgol SC, Selva D, Richards S, Paver R. Basal cell carcinoma treated with Mohs surgery in Australia I. Experience over 10 years. J Am Acad Dermatol 2005; 53: 445-451.

10. Rowe DE, Carroll RJ, Day CL, Jr. Prognostic factors for local recurrence, metastasis, and survival rates in squamous cell carcinoma of the skin, ear, and lip. Implications for treatment modality selection. J Am Acad Dermatol 1992; 26: 976-990.

11. Mosterd K, Krekels GA, Nieman FH, Ostertag JU, Essers BA, Dirksen $C D$, et al. Surgical excision versus Mohs' micrographic surgery for primary and recurrent basal-cell carcinoma of the face: a prospective randomised controlled trial with 5-years' follow-up. Lancet Oncol 2008; 9: 1149-1156. 
12. Smeets NW, Krekels GA, Ostertag JU, Essers BA, Dirksen CD, Nieman FH, et al. Surgical excision vs Mohs' micrographic surgery for basal-cell carcinoma of the face: randomised controlled trial. Lancet 2004; 364: 1766-1772.

13. Van Loo E, Mosterd K, Krekels GA, Roozeboom MH, Ostertag JU, Dirksen CD, et al. Surgical excision versus Mohs' micrographic surgery for basal cell carcinoma of the face: A randomised clinical trial with 10 year follow-up. Eur J Cancer 2014; 50: 3011-3020.

14. Muller FM, Dawe RS, Moseley H, Fleming CJ. Randomized comparison of Mohs micrographic surgery and surgical excision for small nodular basal cell carcinoma: tissue-sparing outcome. Dermatol Surg 2009; 35: 1349-1354.

15. Leibovitch I, Huilgol SC, Selva D, Richards S, Paver R. Basal cell carcinoma treated with Mohs surgery in Australia II. Outcome at 5-year follow-up. J Am Acad Dermatol 2005; 53: 452-457.

16. Tschetter AJ, Campoli MR, Zitelli JA, Brodland DG. Longterm clinical outcomes of patients with invasive cutaneous squamous cell carcinoma treated with Mohs micrographic surgery: a 5-year, multicenter, prospective cohort study. J Am Acad Dermatol 2020; 82: 139-148.

17. Drucker AM, Adam GP, Rofeberg V, Gazula A, Smith B, Moustafa $F$, et al. Treatments of primary basal cell carcinoma of the skin: a systematic review and network meta-analysis. Ann Intern Med 2018; 169: 456-466.

18. Motley R, Arron S. Mohs micrographic surgery for cutaneous squamous cell carcinoma. Br J Dermatol 2019; 181: 233-234.

19. Delgado Jimenez Y, Camarero-Mulas C, Sanmartin-Jimenez O, Garces JR, Rodriguez-Prieto MA, Alonso-Alonso T, et al. Differences of Mohs micrographic surgery in basal cell carcinoma versus squamous cell carcinoma. Int J Dermatol 2018; 57: 1375-1381.

20. Ruiz-Salas V, Garces JR, Minano Medrano R, Alonso-Alonso T, Rodriguez-Prieto MA, Lopez-Estebaranz JL, et al. Description of patients undergoing Mohs surgery in Spain: initial report on data from the Spanish Registry of Mohs surgery (REGESMOHS). Actas Dermosifiliogr 2015; 106: 562-568.

21. Alonso-Alonso T, Redondo-Bellon P, Sanmartin-Jimenez O, de Eusebio-Murillo E, Garcia-Doval I, Rodriguez-Prieto MA. Census of centers that perform Mohs' micrographic surgery in Spain and description of their activity: a feasibility study for the Mohs' Micrographic Surgery Registry of the Foundation of the Spanish Academy of Dermatology and Venereology. Actas Dermosifiliogr 2015; 106: 764-766.

22. Smeets NW, Kuijpers DI, Nelemans P, Ostertag JU, Ver- haegh ME, Krekels GA, et al. Mohs' micrographic surgery for treatment of basal cell carcinoma of the face - results of a retrospective study and review of the literature. $\mathrm{Br}$ J Dermatol 2004; 151: 141-147.

23. Dzubow LM, Rigel DS, Robins P. Risk factors for local recurrence of primary cutaneous squamous cell carcinomas. Treatment by microscopically controlled excision. Arch Dermatol 1982; 118: 900-902.

24. Marrazzo G, Zitelli JA, Brodland D. Clinical outcomes in highrisk squamous cell carcinoma patients treated with Mohs micrographic surgery alone. J Am Acad Dermatol 2019; 80: 633-638.

25. Eigentler TK, Leiter U, Hafner HM, Garbe C, Rocken M, Breuninger $\mathrm{H}$. Survival of patients with cutaneous squamous cell carcinoma: results of a prospective cohort study. J Invest Dermatol 2017; 137: 2309-2315.

26. Julian CG, Bowers PW. A prospective study of Mohs' micrographic surgery in two English centres. Br J Dermatol 1997; 136: 515-518.

27. Mohs FE. Chemosurgery for the microscopically controlled excision of cutaneous cancer. Head Neck Surg 1978; 1: 150-166.

28. Mohs FE. Chemosurgery: microscopically controlled surgery for skin cancer - past, present and future. J Dermatol Surg Oncol 1978; 4: 41-54.

29. Robins P. Chemosurgery: my 15 years of experience. J Dermatol Surg Oncol 1981; 7: 779-789.

30. Veronese F, Farinelli P, Zavattaro E, Zuccoli R, Bonvini D, Leigheb $G$, et al. Basal cell carcinoma of the head region: therapeutical results of 350 lesions treated with Mohs micrographic surgery. J Eur Acad Dermatol Venereol 2012; 26: 838-843.

31. Weesie F, Naus NC, Vasilic D, Hollestein LM, van den Bos RR, Wakkee M. Recurrence of periocular basal cell carcinoma and squamous cell carcinoma after Mohs micrographic surgery: a retrospective cohort study. $\mathrm{Br}$ J Dermatol 2019; 180: 1176-1182.

32. Leibovitch I, Huilgol SC, Selva D, Hill D, Richards S, Paver R. Cutaneous squamous cell carcinoma treated with Mohs micrographic surgery in Australia II. Perineural invasion. J Am Acad Dermatol 2005; 53: 261-266.

33. Holmkvist KA, Roenigk RK. Squamous cell carcinoma of the lip treated with Mohs micrographic surgery: outcome at 5 years. J Am Acad Dermatol 1998; 38: 960-966.

34. Pugliano-Mauro M, Goldman G. Mohs surgery is effective for high-risk cutaneous squamous cell carcinoma. Dermatol Surg 2010; 36: 1544-1553. 